\title{
СРАВНИТЕЛЬНЫЙ АНАЛИЗ ВЛИЯНИЯ ФАКТОРОВ РИСКА НА ТЕЧЕНИЕ И ИСХОДЫ БЕРЕМЕННОСТИ ПРИ ГЕСТАЦИОННОМ САХАРНОМ ДИАБЕТЕ
}

\author{
Михеев Р.К. ${ }^{1}$, Григорян О.Р. ${ }^{1},$. Ибрагимова Л.И ${ }^{1}$, Дегтярева Е.И. ${ }^{2}$, Андреева Е.Н. ${ }^{13}$ \\ 'ФГБУ «Национальный медицинский исследовательский чентр эндокринологии» Минздрава России, Москва.

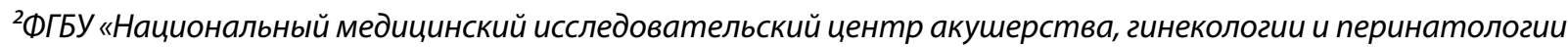 \\ им. В.И.Кулакова» Минздрава России, Москва.

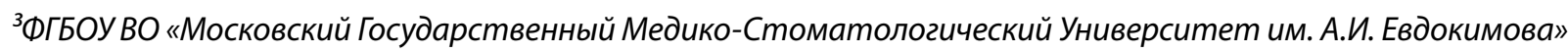 \\ Минздрава России, Москва.
}

ЦЕЛЬ: Оценить структуру факторов риска развития ГСД, выявить взаимосвязь между ГСД, течением и исходами беременности путем ретроспективного анализа карт стационарных больных отделения патологии беременности Научного Центра Акушерства, Гинекологии и Перинатологии им. В.И. Кулакова, наблюдавшихся так же в «Национальный медицинский исследовательский центр эндокринологии» Минздрава России.

МАТЕРИАЛЫ И МЕТОДЫ: РетроспективныЙ анализ 79 историй болезни пациенток с подтвержденным ГСД в период с 2017 по 2019 год. Многоцентровое наблюдательное (обсервационное) одномоментное ретроспективное, одновыборочное несравнительное, со сплошным способом формирования выборки.

PEзУЛЬтАТЫ: В структуре факторов риска для матери и плода наибольшее значение имеют возраст матери старше 30 лет (73,1\%), отягощенная наследственность по сахарному диабету 2 типа (СД2) (30,8\%), индекс массы тела (ИМТ) до беременности, соответствующий избыточной массе тела/ожирению (26,9\%). Чаще встречались такие осложнения, как оперативное родоразрешение пациенток путем операции кесарева сечения $(47,4 \%)$. Частота остальных осложнений таких как: макросомия (9\%), преждевременные роды (7,7\%), врожденные пороки развития (ВПР) плода (5,1\%), преэклампсия $(5,1 \%))$, в целом оказалась ниже средней частоты осложнений ГСД, описанной в литературе, тем не менее, в 1,5-2 раза превысила среднепопуляционные показатели. В ходе статистического анализа полученных данных выявлено, что чем больше ИМТ матери до беременности, тем ниже оценка за первую минуту по шкале Апгар у новорожденного. В исследовании не было выявлено ожидаемой корреляционной зависимости между уровнем глюкозы плазмы крови матери и ИМТ матери до беременности ( $r s=-0,11, p=0,42)$, сроком родоразрешения $(r s=-0,04, p=0,78)$, баллами по шкале Апгар на первой $(r s=-0,06 ; p=0,67)$ и пятой минутах $(r s=-0,1, p=0,45)$. В исследования не обнаружилось корреляции между ОПВ и следующими показателями: массой плода $(r s=0,36, p=0,79)$, баллами по шкале Апгар на первой ( $r s=0,36, p=0,79)$ и пятой ( $r s=-0,015, p=0,91)$ минутах.

Выводы: женщины с ГСД требуют интенсивного наблюдения за течением беременности и своевременной госпитализации для планового родоразрешения с целью снижения риска перинатальных осложнений.

КЛЮЧЕВЫЕ СЛОВА: беременность; гестачионный сахарный диабет; гипергликемия; макросомия; преэклампсия. 